\title{
Anti-HBs levels in children under the age of two years born to HBV carrier mothers after immunoprophylaxis: a multicenter cross- sectional study
}

\author{
Min Jiang ${ }^{1}$, Bo Zhu², Qiang Yao ${ }^{1}$, Haifeng Lou ${ }^{3}$ and Xiaohui Zhang ${ }^{4^{*}}$
}

\begin{abstract}
Background: Serological testing for the presence of Hepatitis B Virus (HBV) markers and anti-HBs titers in infants born to HBsAg positive women is critically important for estimation in immunisation programme.

Methods: This was a multi-center and cross-sectional study conducted in Zhejiang province, China. Children aged 7 to 24 months born to HBsAg positive women during December 2018 to February 2019, completed additional HBV serological markers screening. We indicated distribution of HBV serological markers and anti-HBs titers in children. Multiple logistic regression model with adjusted odds ratio and 95\% confidence interval (OR adj and $95 \%$ Cl) was used to explore the factors associated with inadequate immune response (anti-HBs titers $<100 \mathrm{mlU} / \mathrm{ml}$ ) among children.

Results: A total of 1849 children were included. Overall 25 children tested HBsAg positive, giving HBsAg positive rate of 1.35\%(95\% Cl: $0.83-1.88 \%$ ). 92.00\% (23/25) HBsAg positive children were delivered by HBeAg positive mothers. The proportion of protective seroconversion (anti-HBs titers $\geq 10 \mathrm{mlU} / \mathrm{ml}$ ) was $99.29 \%$ in all children, and $86.48 \%$ children were reported with adequate anti-HBs titers $(\geq 100 \mathrm{mlU} / \mathrm{ml})$. We found a significant higher proportions of early antenatal health care ( $<13$ gestational weeks), and term birth in children with adequate response compared with inadequate response (all $P<0.05$ ). Logistic regression showed preterm birth was a negative factor for inadequate anti-HBs titers $\left(\mathrm{OR}_{\mathrm{adj}}=1.868,95 \% \mathrm{Cl} 1.132-3.085, P=0.015\right)$.

Conclusions: Children delivered by HBeAg positive mothers had higher risk of vertical transmission of HBV, despite completion of 3 doses of hepatitis B vaccine and HBIG injection. Inadequate anti-HBs level was significantly associated with preterm birth in HBsAg positive women.
\end{abstract}

Keywords: HBV markers, HBV immune response, HBV carrier women, Preterm birth, Low birth weight

\section{Introduction}

Vertical transmission is the main route for young children to have Hepatitis B Virus (HBV) infection. With the wide coverage of vaccination against HBV and Hepatitis

\footnotetext{
*Correspondence: zjfb_amy@zju.edu.cn

${ }^{4}$ Department of Women's Health, Women's Hospital, School of Medicine,

Zhejiang University, Xueshi Road 1, Hangzhou, Zhejiang 310006, People's Republic of China

Full list of author information is available at the end of the article
}

B immune globulin (HBIG) for newborns from HBVinfected women, mother to child transmission (MTCT) of HBV has declined globally [1-4]. In some countries or regions, $\mathrm{HBsAg}$ positive rates in children at age five was even less than 1\% [3, 5]. In 2016, World Health Organization (WHO) called for ending HBV as a public health threat with the achievement goal of sustainable development (2030), aiming to reduce HBV prevalence under $1 \%$ by 2020 and under $0.1 \%$ by 2030 among children at 
the age of five $[4,5]$. Nevertheless, there were still gaps to meet the global HBV elimination goal due to the disparity in social-economical development, HBV epidemiology and coverage of prevention MTCT [2-7]. For example, some countries or regions in Africa and Asia still face high endemic of HBV, particularly in women without vaccination $[7,8]$. In central and eastern Europe, only $75 \%$ countries provide universal HBV screening for pregnant women [6]. Globally, less than 50\% countries are available for providing first $\mathrm{HBV}$ vaccine dose within $24 \mathrm{~h}$ by WHO [2].

HBV vaccination along with HBIG are effective to reduce MTCT [2]. Postvaccination serological testing (PVST) is important for evaluating the immunization effects, although it is not routinely performed in some countries. In some previous studies, no response, protective response, adequate response and high response to vaccine were regarded as anti-HBs titers $<10 \mathrm{mIU} /$ $\mathrm{mL}$, anti-HBs $\geq 10 \mathrm{mIU} / \mathrm{mL}$, anti-HBs $\geq 100 \mathrm{mIU} / \mathrm{mL}$, and anti-HBs $\geq 1000 \mathrm{mIU} / \mathrm{mL}$, respectively [9-11]. Anti$\mathrm{HBs} \geq 10 \mathrm{mIU} / \mathrm{mL}$ is widely considered as a seroprotective response to vaccine [9]. Furthermore, some studies preferred anti-HBs titer exceeding $100 \mathrm{mIU} / \mathrm{mL}$ as protective effect $[11,12]$.Anti-HBs titer less than $100 \mathrm{mIU} /$ $\mathrm{mL}$ was indicated as risk factor for HBV reactivation, and booster vaccination was suggested [11, 13]. A study showed that after completion of $\mathrm{HBV}$ immunization course in infancy;5-20\% infants encountered vaccination failure or poor response [9-14]. Currently, there are a few studies on infant seroprotective level of anti-HBs over $100 \mathrm{mIU} / \mathrm{mL}$.

China has the largest burden of HBV infection in the world with $5-6 \%$ prevalence and estimated number of HBsAg carriers around 70 million [15]. Chinese government has made great efforts to control HBV. Since 1992, an integrated national immunization programs have included 3 doses of HBV vaccine for infants within $24 \mathrm{~h}$ of birth, and subsequently at one and 6 months of birth [1]. Following this, a national strategy of preventing mother to child transmission (PMTCT) of HBV was implemented in China in 2010 [16]. This includes routine HBV screening for pregnant women during their first antenatal health care visit (ANC), and timely vaccine with HBIG for all newborns from $\mathrm{HBsAg}$ positive women. PVST is recommend for infants born to HBsAg positive women but not funded by government. Although, China has made great achievement in combating HBV over the past decades, persisting efforts on HBV prevention is still needed considering huge population and geographical variety [15-17]. Zhejiang Province is a relatively developed area in Eastern China with approximately 60 million residents, where the prevalence of $\mathrm{HBsAg}$ in people aged 1 to 29 years was $1.05 \%$ in 2014
[18]. Since 2016, Chinese Center for Disease Control and Prevention initiated and funded PVST in Zhejiang. One year later, Zhejiang was appointed as a pilot province for the elimination MTCT (EMTCT) of HIV, Syphilis and HBV in China. The coverage, timeliness and completeness of $\mathrm{HBV}$ vaccine improved greatly over the past decades, reaching 94-98\% in 2017 [19]. To accelerate the progress towards eradication of $\mathrm{HBV}$, we performed the study to verify the HBsAg positive rates, anti-HBs titers and factors associated with adequate immune response among children under two years old, delivered by HBsAg positive women in Zhejiang province. The findings would be of significance for guiding HBV EMTCT.

\section{Materials and methods \\ Study design and subjects}

This was a multi-center cross-sectional study. We enrolled subjects in eight urban and rural regions (Ouhai, Pujiang, Ruian,Yuhang, Cixi, Huangyan, Jiaojiang, Ninghai) of Zhejiang province by multi-step sampling according to location, maternal $\mathrm{HBsAg}$ positive rate and live births. A total of 2000 singletons aged $7-24$ months and born to HBsAg positive women were recruited during December 2018 to February 2019. A structural questionnaire was used for data collection by medical staff in local women and children's hospital. We performed a face to face interview with children's parents or guardians in each local hospital. Information regarding on maternal social-demographic characteristics, ANC, maternal HBV infection status, birth outcomes, HBV immunization and feeding pattern were recorded. All participants were given an informed consent and agreed to participate. The study was approved by Ethnic Committee of Women's Hospital School of Medicine Zhejiang University.

\section{EMTCT HBV project}

According to Zhejiang provincial HBV EMTCT project, all pregnant women are required to receive $\mathrm{HBsAg}$ screening during their first ANC visit and before delivery. HBsAg positive women routinely get further serology testing and HBV DNA tested. Antiviral treatment is recommended to high risk women (a viral load threshold of $2 \times 10^{5} \mathrm{IU} / \mathrm{ml}$ or $\mathrm{HBeAg}$ positive) from 24 gestational weeks. All infants are recommended to receive the first dose of HBV vaccine within $24 \mathrm{~h}$ after birth, followed by the second dose at one month and third dose at 6 months of birth. To prevent mother to child transmission, infants born to HBsAg positive women are vaccinated after birth with $100 \mathrm{IU}$ HBIG within $12 \mathrm{~h}$ (as early as possible) in delivery hospital, in conjunction with HBV vaccination. We suggest all infants to receive the HBV vaccination impact estimation at least one month later after the third dose, but it is not a mandatory requirement. 


\section{Serological tests}

In the study, all serum specimens were tested in the laboratory of Women's Hospital, School of Medicine Zhejiang University. HBV serological markers presented as Hepatitis B surface antigen ( $\mathrm{HBsAg})$, antibody against HBsAg (anti-HBs), Hepatitis B e antigen (HBeAg), antibody against $\mathrm{HBeAg}$ (anti-HBe), and antibody against Hepatitis B core antigen (anti-HBc). These five HBV markers were detected by Chemiluminescent Enzyme Immunoassay (CLEIA) with automated immunoassay analyzer (HISCL-5000; Sysmex corporation, Japan). Serum HBsAg and anti-HBs are determined quantitatively while serum $\mathrm{HBeAg}$, anti-HBs, and anti-HBc were determined qualitatively. Specimens with concentrations $\geq 0.03 \mathrm{IU} / \mathrm{mL}$ were considered as positive by HBsAg criteria and $\geq 10 \mathrm{mIU} / \mathrm{mL}$ as positive on anti-HBs testing.

\section{Sampling method and statistical analysis}

We assumed the HBV MTCT would be about $2 \%$. The calculated average sample size is 169 in each region when we assume $80 \%$ power, $95 \%$ confidence level, and the precision at $5 \%$. In consideration of the number of regions, the final sample size was 2000 considering $20 \%$ possible missing data. PASS 11.0 was used to calculate sample size. We defined adequate immune response as anti-HBs titers $\geq 100 \mathrm{mIU} / \mathrm{mL}$, and others as inadequate.

Distribution of children HBV markers and anti-HBs levels were presented with number and proportion. Chisquare test was used to compare differences between women and children's adequate and inadequate response characteristics. Multiple logistic regression model with Odds ratio and 95\% confidence interval (OR and 95\% $C I$ ) was used to explore the risk factors associated with inadequate immune response in children. Significant differences were considered as $P$ value $<0.05$ with two side effects. All data were double-inputted and checked for consistency using EPI Data software (version 3.02, The EpiData Association).We conducted statistics analysis using SPSS 16.0.

\section{Results}

A total of 1849 children were involved in this study finally. Of these, $23.20 \%$ (429) were born to $\mathrm{HBeAg}$ positive women who had first HBV screening during pregnancy. Overall, there were 967 boys, 875 girls and 7 unknown gender. The average age of children was $15.30 \pm 3.98$ months, with a median age of 15.00 months. All children completed three doses of hepatitis B vaccine, including 99.13\%(1833) children with $10 \mu \mathrm{g} /$ dose vaccine and $0.87 \%(16)$ without clear information on specific dose of vaccine.94.38\% (1745) infants had their first dose of $\mathrm{HBV}$ vaccine within $6 \mathrm{~h}$ after birth, $2.33 \%(43)$ between
6 and $12 \mathrm{~h}, 2.70 \%$ (50) between 13 and 24h,0.11\% (2) beyond 24 hours after birth and $0.49 \%$ (9) without specific information. Similarly, 95.08\% (1758) infants had HBIG within $6 \mathrm{~h}$ after birth, $1.94 \%$ (36) between 7 and $12 \mathrm{~h}$, $2.60 \%$ (48) between 13 and $24 \mathrm{~h}$ and $0.38 \%$ (7) infants beyond $24 \mathrm{~h}$ after birth.

In the study, 1824 children tested negative for HBsAg. 25 children were $\mathrm{HBsAg}$ positive, giving overall $\mathrm{HBsAg}$ positive rate $1.35 \%$ (95\% CI $0.83-1.88 \%$ ). $92.00 \%$ (23/25) $\mathrm{HBsAg}$ positive children were born to $\mathrm{HBeAg}$ positive women. $30.43 \%(7 / 23)$ of these $\mathrm{HBeAg}$ positive women received their first ANC beyond 13 gestational weeks. However, only one HBeAg positive woman who delivered HBsAg positive infant had antiviral treatment. In children with negative HBsAg, $2.14 \%$ tested both anti-HBc positive and anti-HBe positive, and $0.99 \%$ tested only anti-HBc positive.

Anti-HBs titers in HBsAg negative children ranged from $0.13 \mathrm{mIU} / \mathrm{mL}$ to $8976.11 \mathrm{mIU} / \mathrm{mL}$. The seroprotection rate (anti-HBs titers $\geq 10 \mathrm{mIU} / \mathrm{mL}$ ) was $99.29 \%$ (1811/1824). The proportion of children with adequate anti-HBs titers $(\geq 100 \mathrm{mIU} / \mathrm{mL})$ was $87.34 \%(1593 / 1824)$. Non-response was observed in $0.71 \%(13 / 1824)$ children (Table 1).

No significant differences were observed in distribution of maternal age, gravidity, parity, employment, maternal HBsAg status maternal abnormal Glutamic-pyruvic Transaminase (ALT) or Glutamic Oxaloacetic Transaminase (AST), delivery mode, boys or girls,low birth weight (LBW) feeding mode and injection time of HBIG between adequate and inadequate immunization groups. Children with adequate response had significant higher proportion of maternal early ANC, and lower proportion

Table 1 Distribution of HBV markers in children

\begin{tabular}{|c|c|c|c|}
\hline Subtype & & Number & Proportion (\%) \\
\hline \multirow[t]{4}{*}{$\mathrm{HBsAg}+$} & & 25 & 1.35 \\
\hline & $\mathrm{HBeAg}+$ & 23 & 1.24 \\
\hline & $\mathrm{HBeAg}+$, anti-HBC+ & 20 & 1.08 \\
\hline & anti-HBe+,anti-HBC+ & 0 & 0 \\
\hline \multirow[t]{8}{*}{ HBsAg- } & & 1824 & \\
\hline & $\begin{array}{l}\text { anti-HBC+, anti-HBs - } \\
\text { HBeAg-, anti-HBe- }\end{array}$ & 18 & 0.99 \\
\hline & $\begin{array}{l}\text { anti-HBC+, anti-HBe }+, \\
\text { anti-HBs -,HBeAg- }\end{array}$ & 39 & 2.14 \\
\hline & $\begin{array}{l}\text { anti-HBs }+ \text {,anti-HBe }+ \\
\text { anti-HBC+, } \mathrm{HBeAg}-\end{array}$ & 0 & \\
\hline & anti-HBs $\geq 10 \mathrm{mlU} / \mathrm{ml}$ & 1811 & 99.29 \\
\hline & anti-HBs $\geq 100 \mathrm{mlU} / \mathrm{ml}$ & 1593 & 87.34 \\
\hline & $\begin{array}{l}10 \mathrm{mlU} / \mathrm{ml} \leq \text { anti-HBs }<100 \mathrm{mlU} / \\
\mathrm{ml}\end{array}$ & 218 & 11.95 \\
\hline & anti-HBs $<10 \mathrm{mlU} / \mathrm{ml}$ & 13 & 0.71 \\
\hline
\end{tabular}


Table 2 Comparison between women and children's adequate and inadequate response characteristics

\begin{tabular}{|c|c|c|c|c|c|c|c|}
\hline \multirow[t]{3}{*}{ Variable } & & \multirow{2}{*}{\multicolumn{2}{|c|}{$\begin{array}{l}\text { Adequate responders } \\
(N=1593)\end{array}$}} & \multirow{2}{*}{\multicolumn{2}{|c|}{$\frac{\text { Inadequate responders }}{(N=231)}$}} & \multirow[t]{3}{*}{$x^{2}$} & \multirow[t]{3}{*}{$P$} \\
\hline & & & & & & & \\
\hline & & $\mathbf{n}$ & $\%$ & $\mathbf{n}$ & $\%$ & & \\
\hline \multirow[t]{4}{*}{ Maternal age } & $<25$ & 93 & 86.11 & 15 & 13.89 & \multirow[t]{4}{*}{2.151} & \multirow[t]{4}{*}{0.542} \\
\hline & $25-29$ & 528 & 88.29 & 70 & 11.71 & & \\
\hline & $30-34$ & 557 & 85.96 & 91 & 14.04 & & \\
\hline & $\geq 35$ & 415 & 88.3 & 55 & 11.7 & & \\
\hline \multirow[t]{4}{*}{ Gravidity } & 1 & 387 & 84.87 & 69 & 15.13 & \multirow[t]{4}{*}{3.988} & \multirow[t]{4}{*}{0.136} \\
\hline & 2 & 489 & 87.17 & 72 & 12.83 & & \\
\hline & $\geq 3$ & 711 & 88.76 & 90 & 11.24 & & \\
\hline & Missing & 6 & 100 & 0 & 0 & & \\
\hline \multirow[t]{4}{*}{ Parity } & 1 & 10 & 100 & 0 & 0 & \multirow[t]{4}{*}{1.834} & \multirow[t]{4}{*}{0.400} \\
\hline & 2 & 614 & 87.84 & 85 & 12.16 & & \\
\hline & $\geq 3$ & 965 & 86.86 & 146 & 13.14 & & \\
\hline & Missing & 4 & 100 & 0 & 0 & & \\
\hline \multirow[t]{3}{*}{ First antenatal care } & first trimester & 1244 & 88.04 & 169 & 11.96 & \multirow[t]{3}{*}{6.962} & \multirow[t]{3}{*}{0.031} \\
\hline & Second trimester & 298 & 86.38 & 47 & 13.62 & & \\
\hline & Third trimester & 51 & 77.27 & 15 & 22.73 & & \\
\hline \multirow{4}{*}{$\begin{array}{l}\text { Employment } \\
\text { status }\end{array}$} & Fixed employment & 241 & 88.28 & 32 & 11.72 & \multirow[t]{4}{*}{1.022} & \multirow[t]{4}{*}{0.796} \\
\hline & Service & 364 & 87.5 & 52 & 12.5 & & \\
\hline & Farmer & 105 & 84.68 & 19 & 15.32 & & \\
\hline & Unemployed & 883 & 87.34 & 128 & 12.66 & & \\
\hline \multirow[t]{3}{*}{ Maternal HBeAg during first ANC } & $\mathrm{HBeAg}+$ & 352 & 86.06 & 57 & 13.94 & \multirow[t]{3}{*}{0.994} & \multirow[t]{3}{*}{0.319} \\
\hline & HBeAg - & 1030 & 87.96 & 141 & 12.04 & & \\
\hline & Unknown & 211 & 86.48 & 33 & 13.52 & & \\
\hline ALT/AST & Normal & 1369 & 87.03 & 204 & 12.97 & 3.439 & 0.064 \\
\hline & abnormal & 109 & 81.34 & 25 & 18.66 & & \\
\hline & missing & 115 & 98.29 & 2 & 1.71 & & \\
\hline Mode of delivery & Vaginal delivery & 812 & 88.17 & 109 & 11.83 & 0.535 & 0.465 \\
\hline & Cesarean section & 758 & 87.03 & 113 & 12.97 & & \\
\hline & Missing & 23 & 71.88 & 9 & 28.13 & & \\
\hline Gender of children & Female & 747 & 86.66 & 115 & 13.34 & 0.692 & 0.406 \\
\hline & Male & 840 & 87.96 & 115 & 12.04 & & \\
\hline & Missing & 6 & 85.71 & 1 & 14.29 & & \\
\hline Low birth weight $(<2500 \mathrm{~g})$ & Yes & 40 & 78.43 & 11 & 21.57 & 3.761 & 0.052 \\
\hline & No & 1553 & 87.59 & 220 & 12.41 & & \\
\hline Preterm & Yes & 81 & 79.41 & 21 & 20.59 & 6.147 & 0.013 \\
\hline & No & 1512 & 87.91 & 208 & 12.09 & & \\
\hline & Missing & 13 & 86.67 & 2 & 13.33 & & \\
\hline Feeding within 6 months & Breast & 683 & 89.05 & 84 & 10.95 & 3.839 & 0.147 \\
\hline & Mixed & 432 & 85.54 & 73 & 14.46 & & \\
\hline & Artificial & 474 & 86.5 & 74 & 13.5 & & \\
\hline & Missing & 4 & 100 & 0 & 0 & & \\
\hline $\mathrm{HBIG}$ & Within $12 \mathrm{~h}$ & 1503 & 87.28 & 219 & 12.72 & 0.079 & 0.779 \\
\hline & Over $12 \mathrm{~h}$ & 90 & 88.24 & 12 & 11.76 & & \\
\hline
\end{tabular}


of preterm birth than those with anti-HBs titers under $100 \mathrm{mIU} / \mathrm{mL}$ (Table 2). Multiple logistic regression mode showed only preterm birth $\left(\mathrm{OR}_{\mathrm{adj}}=1.868,95 \% \mathrm{CI}\right.$ $1.132-3.085, P=0.015$ ), adjusted for LBW and ANC was strongly associated with anti-HBs titers under 100 (mIU/ $\mathrm{mL}$ ).

\section{Discussion}

In our study, the overall HBsAg positive rate was $1.35 \%$ among children aged 7-24months. The global estimation of HBV infection prevalence in children at 5 years old in 2016 was $1.4 \%$ [20]. Our HBsAg positive rate was lower than studies performed in Japan (1.9\%), Malaysia (2.6\%), and Denmark(2.3\%), targeted on infants, young children or adolescents born from HBV carrier mothers [21-23]. In China, HBsAg positive rate ranged from $0.35 \%$ in children at the age of 7 months to 12 years in Jiangsu, 4.9 and $1.4 \%$ in children of $13-24$ months and 7-12 months in 4 northwest provinces, and $0.9 \%$ in children aged 7-22 months in Hebei Guangdong Shanxi and Zhejiang [24-26]. We noticed over 90\% HBsAg positive children were born to $\mathrm{HBeAg}$ positive women. Among HBsAg positive children, HBeAg positive was prevalent. Delay of first ANC in $\mathrm{HBeAg}$ positive women might delay treatment, possibly increasing the risk of vertical transmission. In this study, only one $\mathrm{HBeAg}$ positive woman who delivered HBsAg positive child received treatment. We also noticed no vertical transmission occurred in the children delivered by women who had effect antiviral treatment, corresponding to previous report [27]. Therefore, antiviral treatment should be given priority in $\mathrm{HBeAg}$ positive women.

Combined passive and active immunization greatly contributed to reduction of HBV infection. A metaanalysis covering 26 studies showed people without vaccination had substantially higher $\mathrm{HBsAg}$ prevalence than those universally vaccinated [28]. We noted that over $99 \%$ of children developed protective anti-HBs $(\geq 10 \mathrm{mIU} / \mathrm{mL})$, and $87.34 \%$ children with anti-HBs levels $\geq 100 \mathrm{mIU} / \mathrm{ml}$. Previous studies showed protective seroconversion rates varied with children's age and disease. The anti-HBs positivity rate ranged from around $70 \%$ to beyond $95 \%$ in normal infants or adolescents $[10,12,14,29]$, but only around $50 \%$ among school age children with disease, such as autism spectrum disorders orceliac disease [30, 31]. In our study, the proportion of children with anti-HBs titers at or over $100 \mathrm{mIU} /$ $\mathrm{mL}$ were slightly less than infant in Changchun at age of 7-12 months(96.5\%), but far higher than infants at 1 year in Chongqing (67.8\%) and Al-Quds University $(62.3 \%)[9,11,32]$. In theory, antibody levels naturally declined by age, particularly more rapidly in children over 5 years old $[10,11,32]$. It was shown that over $90 \%$ children with initial vaccination failure might be revaccinated successfully [10]. A few proportion of children who tested HBsAg negative were anti-HBc positive. This indicated that these children might have occult HBV infection or have high risk of viral reactivation. Therefore, to analyse the HBV markers in serum is helpful for new intervention programme.

Parent HBV status, maternal HBV-DNA, timely and complete intervention, genetic effects and feeding mode were common determines for $\mathrm{HBV}$ vaccination response [9, 12, 26, 29, 32-34]. Overall, a genetic effect could explain $70-90 \%$ HBV vaccine responses, the remaining were unknown or environment factors [12]. Nevertheless, few studies focused on the risk factors related to anti-HBs titers under $100 \mathrm{mIU} / \mathrm{mL}$. In our study, the negative association between LBW and anti-HBs less than $100 \mathrm{mIU} / \mathrm{mL}$ was consistent with the study in North China and Xinjiang to some extent (both with adjusted $\mathrm{OR}=2.5)[9,12] . \mathrm{LBW}$ or preterm birth were the common reasons for delay in vaccination, which possibly lead to no or inadequate response. Breast feeding did not increase the risk of poor vaccination response in our study as previously reported $[9,33,34]$. In the United States, women with HBV infection are widely encouraged to breast-feed if the infant receives HBV vaccination and Hepatitis B immunoglobulin fully, which is similar to our province [34].

It has been widely evidenced that positive maternal HBeAg infection increases risks of MTCT [25, 35-37]. For $\mathrm{HBeAg}$ positive mothers, higher HBV-DNA level was strongly associated with increased risk for poor response to vaccination [9]. Exploration of risks related to maternal viral load in our study was limited due to lack of specific information, notably only 64 women had clear records of HBV DNA testing. The association between high antiHBs titres and maternal HBeAg status is unclear. As previously suggested, protective effect is significant when infants born to HBeAg positive women were injected 20 $\mu \mathrm{g} H B V$ vaccine within $2 \mathrm{~h}$ after birth [9]. Exploration of different immunization projects according to maternal HBV status should be given much consideration.

In this study, we focused on inadequate response to HBV vaccine in children. This provides further helpful information for HBV vaccination and EMTCT, particularly for high risk women and their infants. There were several limitations in our study. Firstly, the study did not involve fathers basic information, which may also indicate source of children's infection [38, 39]. Secondly, we only recruited local resident children and singletons births, which might bring some selective bias. Thirdly, influences by maternal viral load and treatment was not involved due to limited data. 


\section{Conclusions}

Hepatitis B vaccine and HBIG injection would result in protective antibody in over $99 \%$ infants. Preterm birth need to be considered for inadequate response to the vaccine. Moreover complete routine infant HBV vaccination, vertical transmission was observed in infants born to $\mathrm{HBeAg}$ positive women.

\begin{abstract}
Abbreviations
HBV: Hepatitis B virus; HBIG: Hepatitis B Immunoglobulin; OR: Odds Ratio; ORadj: Adjusted Odds Ratio; Cl: Confidence Interval; anti-HBs: anti-HBV Surface Antigen; MTCT: Mother to Child Transmission; HBsAg: Hepatitis B Surface Antigen; WHO: World Health Organization; PVST: Postvaccination serological testing; PMTCT: Preventing mother to child transmission; EMTCT: Elimination MTCT; HBeAg: Hepatitis B e antigen; anti-HBe: Antibody against Hepatitis B e antigen; anti-HBC: Antibody against Hepatitis B core antigen; ANC: Antenatal health care; CLEIA: Chemiluminescent Enzyme Immunoassay; ALT: Glutamicpyruvic Transaminase; AST: Glutamic Oxaloacetic Transaminase; LBW: Low birth weight.
\end{abstract}

\section{Acknowledgments}

The authors would like to thank all of the medical staff who participated in this study, particularly those working in local women and children's hospitals.

\section{Code availability}

Not Applicable.

\section{Authors' contributions}

X.Z is responsible for the study. M.J,B.Z and Q.Y conceived the study and drafted the manuscript. B.Z conducted laboratory supervision. Q.Y did statistics analysis. H.L performed data collection and quality control. X.Z provided technical assistance and revised the article. All authors read and approved the final manuscript.

\section{Funding}

The study was funded by UNICEF China,501 Health, Nutrition and Wash- MCH; Increased evidence and policy makers' capacity Piloting, Elimination of mother to child transmission of HIV, syphilis and HBV (EMTCT) and Key R\&D Projects of Sichuan Province (Grant/Award Number: 2019YFS0409). Funding for data collection. These funders had no role in study design, data interpretation and manuscript writing.

\section{Availability of data and materials}

The datasets generated and/or analysed during the current study are not publicly available but are available from the corresponding author on reasonable request.

\section{Declarations}

\section{Ethics approval and consent to participate}

The study was approved by Ethnic Committee of Women's Hospital School of Medicine Zhejiang University. Written informed consent was obtained from the parents. All methods were performed in accordance with the ethical principles of the Declaration of Helsinki 2000.

\section{Consent for publication}

Not Applicable.

\section{Competing interests}

The authors declare that they have no conflict of interest.

\section{Author details}

${ }^{1}$ Department of Epidemiology and Health Statistics, West China School of Public Health and West China Fourth Hospital, Sichuan University, No. 17 Section 3, Renmin South Road, Chengdu, Sichuan 610041, People's Republic of China. ${ }^{2}$ Department of Medical Laboratory Science, Women's Hospital,
School of Medicine, Zhejiang University, Xueshi Road 1, Hangzhou, Zhejiang 310006, People's Republic of China. ${ }^{3}$ Department of Obstetrics, Women's Hospital, School of Medicine, Zhejiang University, Xueshi Road 1, Hangzhou, Zhejiang 310006, People's Republic of China. ${ }^{4}$ Department of Women's Health, Women's Hospital, School of Medicine, Zhejiang University, Xueshi Road 1, Hangzhou, Zhejiang 310006, People's Republic of China.

Received: 29 April 2021 Accepted: 20 October 2021

Published online: 04 November 2021

\section{References}

1. Liao X, Liang Z. Strategy vaccination against hepatitis B in China. Hum Vaccin Immunother. 2015;11(6):1534-9. https://doi.org/10.4161/21645 515.2014 .980206$.

2. Thio CL, Guo N, Xie C, Nelson KE, Ehrhardt S. Global elimination of mother-to-child transmission of hepatitis B: revisiting the current strategy. Lancet Infect Dis. 2015;15(8):981-5. https://doi.org/10.1016/S14733099(15)00158-9.

3. Woodring J, Pastore R, Brink A, Ishikawa N, Takashima Y, Tohme RA. Progress toward hepatitis B control and elimination of mother-to-child transmission of hepatitis B virus Western Pacific region, 2005-2017. MMWR Morb Mortal Wkly Rep. 2019;68(8):195-200. https://doi.org/10. 15585/mmwr.mm6808a2

4. Hutin Y, Desai S, Bulterys M. Preventing hepatitis B virus infection: milestones and targets. Bull World Health Organ. 2018;96(7):443-443A. https://doi.org/10.2471/BLT.18.215210.

5. GLOBAL HEALTH SECTOR STRATEGY ON VIRAL HEPATITIS 2016-2021 https://www.who.int/hepatitis/strategy2016-2021/ghss-hep/en/

6. Chkhartishvili N, Holban T, Simonović Babić J, Alexiev I, Matičič M, Kowalska J, et al. State of viral hepatitis care in 16 countries of central and eastern European region. Cent Eur J Public Health. 2019;27(3):212-6. https://doi.org/10.21101/cejph.a5486.

7. Shan S, Cui F, Jia J. How to control highly endemic hepatitis B in Asia. Liver Int. 2018;38(Suppl 1):122-5. https://doi.org/10.1111/liv.13625.

8. Bittaye M, Idoko P, Ekele BA, Obed SA, Nyan O. Hepatitis B virus seroprevalence among pregnant women in the Gambia. BMC Infect Dis 2019;19(1):259. https://doi.org/10.1186/s12879-019-3883-9.

9. Wang C, Wang C, Jia ZF, et al. Protective effect of an improved immunization practice of mother-to-infant transmission of hepatitis B virus and risk factors associated with immunoprophylaxis failure. Medicine (Baltimore). 2016;95(34):e4390. https://doi.org/10.1097/MD0000000000004390.

10. Li X, Xu Y, Dong Y, Wu X, Wen SM, Kong F, et al. Monitoring the efficacy of infant hepatitis $B$ vaccination and revaccination in 0 - to 8 -year-old children: protective anti-HBs levels and cellular immune responses. Vaccine. 2018;36(18):2442-9. https://doi.org/10.1016/j.vaccine.2018.03.044.

11. Qawasmi M, Samuh M, Glebe D, Gerlich WH, Azzeh M. Age-dependent decrease of anti-HBs titers and effect of booster doses using 2 different vaccines in Palestinian children vaccinated in early childhood. Hum Vaccin Immunother. 2015;11(7):1717-24. https://doi.org/10.1080/21645515. 2015.1041687.

12. Yan K, Cai W, Cao F, Sun H, Chen S, Xu R, et al. Genetic effects have a dominant role on poor responses to infant vaccination to hepatitis $B$ virus. J Hum Genet. 2013;58(5):293-7. https://doi.org/10.1038/jhg.2013. 18.

13. Svicher V, Salpini R, Malagnino V, Piermatteo L, Alkhatib M, Cerva C, et al. New Markers in Monitoring the Reactivation of Hepatitis B Virus Infection in Immunocompromised Hosts. Viruses. 2019;11(9). https://doi.org/10. 3390/v11090783.

14. Shindano TA, Mbusa RK, Kabamba BM, Fiasse R, Horsmans Y. Immunisation after hepatitis B polyvalent vaccination among children in south Kivu Province, Democratic Republic of the Congo. S Afr Med J. 2019;109(5):319-22. https://doi.org/10.7196/SAMJ.2019.v109i5.12819.

15. Liu J, Liang W, Jing W, Liu M. Countdown to 2030: eliminating hepatitis B disease, China. Bull World Health Organ. 2019;97(3):230-8. https://doi. org/10.2471/BLT.18.219469.

16. Wang AL, Qiao YP, Wang LH, Fang LW, Wang F, Jin X, et al. Integrated prevention of mother-to-child transmission for human immunodeficiency virus, syphilis and hepatitis B virus in China. Bull World Health Organ. 2015;93(1):52-6. https://doi.org/10.2471/BLT.14.139626. 
17. Jing W, Liu J, Liu M. Eliminating mother-to-child transmission of HBV: progress and challenges in China. Front Med. 2020;14(1):21-9. https://doi. org/10.1007/s11684-020-0744-2.

18. Zhou $Y$, He H, Deng $X$, Yan $R$, Tang $X$, Xie S, et al. Significant reduction in notification and seroprevalence rates of hepatitis $B$ virus infection among the population of Zhejiang Province, China, aged between 1 and 29years from 2006 to 2014. Vaccine. 2017:35(34):4355-61.

19. Hu Y, Chen YP, Wang Y, Liang H. Hepatitis BVaccination among 1999-2017 BirthCohorts in ZhejiangProvince:The DeterminantsAssociated with InfantCoverage. Int J Environ Res Public Health. 2018;15(12):2915. https:// doi.org/10.3390/ijerph15122915.

20. Polaris Observatory Collaborators. Global prevalence, treatment, and prevention of hepatitis B virus infection in 2016: a modelling study. Lancet Gastroenterol Hepatol. 2018;3(6):383-403. https://doi.org/10.1016/S24681253(18)30056-6.

21. Yokoyama K, Kumagai H, Takahashi M, Nagashima S, Okamoto H, Yamagata T. Occult hepatitis $B$ virus infection in immunized children born to carrier mothers. Pediatr Int. 2017;59(9):1010-6. https://doi.org/10.1111/ ped.13352.

22. Chan WK, Yeoh KY, Lim CY, et al. Hepatitis B virus infection among children of hepatitis B surface antigen positive mothers in a Malaysian hospital. Med J Malaysia. 2018;73(3):137-40.

23. Weis N, Cowan S, Hallager S, Lai SM, Lee JL, Leow AHR, et al. Vertical transmission of hepatitis B virus during pregnancy and delivery in Denmark. Scand J Gastroenterol. 2017;52(2):178-84. https://doi.org/10.1080/00365 521.2016 .1244704$.

24. Lin X, Yang J, Lu H, et al. Minimization of hepatitis B infection among children in Jiangsu, China, 12 years after integration of hepatitis B vaccine into the expanded program on immunization. Vaccine. 2016;34(51):645863. https://doi.org/10.1016/j.vaccine.2016.11.022.

25. Wang F, Zhang G, Zheng H, Zhou Y, Zhou G, Wu H, et al. Post-vaccination serologic testing of infants born to hepatitis B surface antigen positive mothers in 4 provinces of China. Vaccine. 2017;35(33):4229-35. https:// doi.org/10.1016/j.vaccine.2017.06.019.

26. Qiao YP, Su M, Song Y, Wang XY, Li Z, Li YL, et al. Outcomes of the national programme on prevention of mother-to-child transmission of hepatitis $B$ virus in China, 2016-2017. Infect Dis Poverty. 2019;8(1):65. https://doi.org/ 10.1186/s40249-019-0576-y.

27. Sheng Q, Ding Y, Li B, Han C, Li Y, Zhang C, et al. Efficacy and safety of nucleos(t)ide analogues to prevent hepatitis B virus mother-to-child transmission in pregnant women with high viremia: real life practice from China. Int J Med Sci. 2018;15(8):796-801. https://doi.org/10.7150/ijms. 25047.

28. Whitford K, Liu B, Micallef J, Yin JK, Macartney K, Van Damme P, et al. Long-term impact of infant immunization on hepatitis $B$ prevalence: a systematic review and meta-analysis. Bull World Health Organ. 2018;96(7):484-97. https://doi.org/10.2471/BLT.17.205153.

29. Chen HL, Zha ML, Cai JY, Qin G. Maternal viral load and hepatitis B virus mother-to-child transmission risk: a systematic review and meta-analysis. Hepatol Res. 2018;48(10):788-801. https://doi.org/10.1111/hepr.13072.
30. Barfi S, Narges C, Pouretemad HR, Poortahmasebi V, Norouzi M, Farahmand $M$, et al. Measurement of serum hepatitis B surface antibody levels in Iranian autistic children and evaluation of immunological memory after booster dose injection in comparison with controls. J Med Virol. 2019;91(7):1272-8. https://doi.org/10.1002/jmv.25429.

31. Rousseff T, Claeys T, Vande Vijver E, Moes N, Vande Velde S, Schelstraete P, et al. Hepatitis $B$ virus vaccination and revaccination response in children diagnosed with celiac disease: a multicentre prospective study. Acta Gastroenterol Belg. 2019;82(1):27-30.

32. Yue $X, G e ~ C, Z$ huge $S, H e ~ H, ~ Y a n g ~ H, X u ~ H$, et al. Changes and analysis of anti-HBs titres after primary immunization in 1- to 16-year-old Chinese children: A hospital-based study. J Viral Hepat. 2018;25(4):373-80. https:// doi.org/10.1111/jvh.12818.

33. Zhang L, Gui X, Fan J, Wang B, Ji H, Yisilafu R, et al. Breast feeding and immunoprophylaxis efficacy of mother-to-child transmission of hepatitis B virus. J Matern Fetal Neonatal Med. 2014;27(2):182-6. https://doi.org/10. 3109/14767058.2013.806901.

34. Society for Maternal-Fetal Medicine (SMFM), Dionne-Odom J, Tita AT, Silverman NS. Hepatitis B in pregnancy screening, treatment, and prevention of vertical transmission. Am J Obstet Gynecol. 2016;214(1):6-14. https://doi.org/10.1016/j.ajog.2015.09.100.

35. Yelemkoure ET, Yonli AT, Montesano C, Ouattara AK, Diarra B, Zohoncon $\mathrm{TM}$, et al. Prevention of mother-to-child transmission of hepatitis B virus in Burkina Faso: screening, vaccination and evaluation of post-vaccination antibodies against hepatitis B surface antigen in newborns. J Public Health Afr. 2018;9(3):816. https://doi.org/10.4081/jphia.2018.816.

36. Cheung KW, Seto MTY, Lao TT. Prevention of perinatal hepatitis B virus transmission. Arch Gynecol Obstet. 2019;300(2):251-9. https://doi.org/10. 1007/s00404-019-05190-0.

37. Lin X, Guo Y, Zhou A, Zhang Y, Cao J, Yang M, et al. Immunoprophylaxis failure against vertical transmission of hepatitis $B$ virus in the Chinese population: a hospital-based study and a meta-analysis. Pediatr Infect Dis J. 2014;33(9):897-903. https://doi.org/10.1097/INF.0000000000000315.

38. Kong Y, Liu Y, Liu X, Li N, Zhu Z, Zhang A, et al. Relationship between themechanism of hepatitis $B$ virus father-infant transmission and pregnancy outcome. Arch Gynecol Obstet. 2017;295(1):253-7. https://doi.org/10. 1007/s00404-016-4231-6.

39. Wang F, Kang W, Zhou W, Su Q, Bi S, Qiu F, et al. Investigation of the risk factors associated with the failure of hepatitis $B$ vaccination of neonates in Yunnan province, China. Int J Infect Dis. 2018;77:90-5. https://doi.org/ 10.1016/j.jij. 2018.09.026

\section{Publisher's Note}

Springer Nature remains neutral with regard to jurisdictional claims in published maps and institutional affiliations.

\footnotetext{
Ready to submit your research? Choose BMC and benefit from:

- fast, convenient online submission

- thorough peer review by experienced researchers in your field

- rapid publication on acceptance

- support for research data, including large and complex data types

- gold Open Access which fosters wider collaboration and increased citations

- maximum visibility for your research: over $100 \mathrm{M}$ website views per year
}

At BMC, research is always in progress.

Learn more biomedcentral.com/submissions 